AgniesZKa ŚwięTeK

Uniwersytet Pedagogiczny, Kraków

\title{
Innowacyjność sieci franczyzowych
}

\section{CZYM JEST INNOWACYJNOŚĆ?}

Innowacyjność to sposób współczesnych przedsiębiorstw na utrzymanie się na zmieniającym się rynku i odpowiedź na potrzeby klientów. Przedsiębiorstwa, by przetrwać, muszą dziś nie tylko sprostać wysokim i stale rosnącym wymaganiom klientów, lecz również wyprzedzić w skuteczności zaspokajania tych potrzeb swoich konkurentów. Zwykle wiąże się to również z kreowaniem nowych potrzeb klientów przez same przedsiębiorstwa, których to potrzeb klienci nie byli wcześniej świadomi, a nie, jak niegdyś, z prostą odpowiedzią na realne zapotrzebowanie na rynku. W rzeczywistości potrzeby te często tak naprawdę nie istnieją i są dopiero tworzone w świadomości klientów, przez osoby zajmujące się działalnością marketingową firmy. Nowe, często zaawansowane technologicznie produkty (w tym również usługi), będące najbardziej klasycznym wyrazem innowacyjności przedsiębiorstw, szybko po wejściu na rynek przestają być towarem deficytowym, a innowacje coraz częściej mają charakter drobnych ulepszeń, niż rewolucyjnych odkryć. Jest to często efekt „planowej innowacyjności” wielkich firm, w szczególności z branży informatycznej, wprowadzających stopniowo na rynek produkty kolejnych generacji, posiadające niewielkie ulepszenia w stosunku do ich poprzednich wersji (choć wiedza ich ośrodków badawczych znacznie wyprzedza rynek) (Turek 2005). Takie postępowanie ma swoje uzasadnienie zarówno w kwestii niwelowania ponoszonego ryzyka, przy wprowadzaniu produktów stopniowo na rynek, jak i w kwestii finansowej - korzyści z każdej kolejnej generacji muszą być większe, niż przy jednorazowym wprowadzaniu produktu na dany moment „doskonałego”. Wymaga to oczywiście od firm bezustannego monitoringu działalności konkurencji, by nie „spóźnić się” ze swoją „,nowością”. Czy taka innowacyjność „zaplanowana”, najbardziej powszechna wśród wielkich przedsiębiorstw i dostarczająca na dzisiejszy rynek najwięcej nowatorskich i wizjonerskich produktów nie jest paradoksalnie zaprzeczeniem innowacji, a jej prawdziwym duchem są tak naprawdę wynalazki tworzone przez małych przedsiębiorców, jak to często bywa, w garażu? Choć wkład wynalazców jest nieoceniony, to odpowiedź na postawione pytanie brzmi chyba jednak „nie”, zważywszy na ogrom dokonań (choć planowych i stopniowych) w wielkich korporacjach. Dowodem jest choćby dorobek firmy Intel Corporation w zakresie 
produkcji chipów komputerowych, opisywany w bardzo ciekawym artykule przez M. Turka (2005): „[...] w okresie od 1971 do 2003 roku, prędkość zegarowa chipów mikroprocesora Intel [...] zwiększyła się do trzech milionów procent, dochodząc obecnie do około trzech miliardów obliczeń na sekundę. W okresie od 1968 do 2003 roku liczba tranzystorów zawartych w jednym chipie wzrosła o ponad dziesięć milionów procent, a liczba tranzystorów, które można kupić za dolara wzrosła o pięć miliardów procent. Wkładu takiego nie można nazwać wkładem o pomniejszym znaczeniu". Geniusz pierwszego wynalazcy komputera elektronicznego był oczywiście podwaliną do tych osiągnięć, bez których firma nie osiągnęłaby takiego postępu, lecz jak się okazuje nie sam wynalazek, a dopiero praca naukowców firmy doprowadziła do powstania tak zaawansowanego technologicznie, a przy tym wygodnego w użyciu, dostępnego i niedrogiego produktu, bez którego większość z nas nie wyobraża sobie dzisiejszego świata.

Abstrahując od rozważań na temat strategii wielkich przedsiębiorstw i podziału zasług, należy stwierdzić niezaprzeczalnie, że innowacyjność technologiczna jest sercem procesu innowacyjności w ogóle i motorem rozwoju gospodarczego, choć, na co autorka chce zwrócić uwagę w niniejszym artykule, nie jedynym jej aspektem.

Klienci dzięki ciągłym ulepszeniom są niejako przyzwyczajeni do innowacji technicznych i stałego rozwoju rynku. Coraz częściej oczekują od przedsiębiorstw już nie tylko nowych produktów, lecz nowych rozwiązań i stałych udogodnień. Jak się okazuje, innowacyjny na współczesnym rynku może być też powrót do tradycyjnego wyrobu (np. wędlin, rękodzieła artystycznego). Innowacyjność nie może się zatem współcześnie ograniczać do tworzenia nowych rozwiązań technologicznych, a następnie wprowadzania ich do produkcji przemysłowej. Innowacyjność przedsiębiorstw to również, zdaniem autorki, obok udoskonalania produktów, poszukiwanie dróg rozwoju zarówno wewnętrznego (organizacji), jak i przestrzennego przedsiębiorstwa.

Spośród przeanalizowanych, najbliższa poglądom autorki jest definicja innowacyjności zaprezentowana przez M. Haffera, który stwierdza: „[...] innowacyjność przedsiębiorstwa można zdefiniować jako jego zdolność do kreowania i efektywnego wdrażania innowacji technicznych, rynkowych i organizacyjnych umożliwiających mu realizowanie celów strategicznych w konkurencyjnym otoczeniu" (Haffer 2004). Takie szerokie rozumienie innowacyjności prezentowane jest również przez J.A. Schumpetera (1960), według którego innowacyjność obejmuje:

- wprowadzenie nowego produktu, lub znaczne udoskonalenie już istniejącego produktu,

- wprowadzenie nowej metody wytwarzania, lub znaczne udoskonalenie istniejącej,

- stworzenie nowego segmentu rynku, lub rozszerzenie przestrzenne rynku,

- zdobycie nowego źródła zaopatrzenia,

- stworzenie nowego typu organizacji przedsiębiorstwa.

Wyliczenie to współcześnie można by zdaniem autorki uzupełnić jeszcze o innowacyjność w zakresie tworzenia i wdrażania przez przedsiębiorstwa niepowtarzalnych działań marketingowych służących skuteczniejszemu wprowadzeniu i dłuższemu utrzymaniu na rynku swoich produktów. Niezależnie jednak od tego, szczególnym rodzajem nowoczesnego modelu biznesu, uwzględniającym wszystkie niemal elementy innowacyjności wskazane przez J.A. Schumpetera, który w Polsce rozwija się od niedawna, a jest przykładem organizacji innowacyjnej na wielu polach, okazuje się być franczyza, której autorka poświęciła uwagę w niniejszym artykule. 


\section{CZYM JEST FRANCZYZA?}

Zgodnie z przyjętą przez autorkę definicją franczyzy, zawartą w Europejskim Kodeksie Etycznym Franczyzy (strona internetowa Polskiej Organizacji Franczyzodawców), franczyza to system marketingu dóbr, usług i technologii, oparty na ścisłej i ciągłej współpracy między prawnie i finansowo odrębnymi przedsiębiorstwami, franczyzodawcą i jego franczyzobiorcami, w ramach której franczyzodawca nadaje swym franczyzobiorcom prawo, a także nakłada obowiązek prowadzenia działalności zgodnie z koncepcją franczyzodawcy. Franczyza jest zatem formą prowadzenia działalności gospodarczej przez niezależnych przedsiębiorców, którzy działają indywidualnie, lecz w ramach sieci, na zasadach ujętych $\mathrm{w}$ podpisanej z franczyzobiorcą umowie.

\section{FRANCZYZA A INNOWACYJNOŚĆ}

Co zatem sprawia, że dobrze znany od wielu lat sposób prowadzenia działalności autorka uznała za innowacyjny? Poszukiwanie odpowiedzi na to pytanie stało się przedmiotem przeprowadzonych przez autorkę w październiku i listopadzie 2011 r. badań i jedocześnie przedmiotem rozważań niniejszego artykułu. Przedmiotem badań była zatem analiza stopnia rozwoju sieci franczyzowych i ich innowacyjnego charakteru w Polsce.

Celami przeprowadzonych przez autorkę badań były:

- określenie zmian liczby sieci franczyzowych i placówek franczyzowych w Polsce,

- określenie głównych branż, w jakich działają w Polsce sieci franczyzowe,

- określenie udziału polskich i zagranicznych systemów franczyzowych na polskim rynku,

- określenie wielkości inwestycji początkowych ponoszonych przez franczyzobiorców w Polsce,

- określenie cech innowacyjnych w organizacji ogółu sieci franczyzowych, oraz wskazanie przykładów innowacji technicznych, rynkowych i organizacyjnych w przedsiębiorstwach franczyzowych.

Dla realizacji powyższych celów przeprowadzono badania, które objęł:

- analizę ilości, wielkości, kapitałochłonności, oraz pochodzenia sieci franczyzowych w Polsce, na podstawie danych statystycznych uzyskanych z „Raportów o rynku franczyzy w Polsce" za lata: 2007-2011, stworzonych przez analityków firmy konsultingowej Profit system,

- analizę wielkości i dynamiki wzrostu liczby sieci franczyzowych w Polsce, na podstawie danych zgromadzonych przez Polską Organizację Franczyzodawców,

- analizę branży działalności i oferty sieci, stopnia ich rozwoju oraz poziomu kapitału koniecznego na rozpoczęcie działalności inwestycji wybranych 372, spośród 660 istniejących sieci franczyzowych w Polsce.

Dane dotyczące wybranych sieci franczyzowych zgromadzonych przez autorkę z oficjalnych stron internetowych sieci, a także w toku przeprowadzanych wywiadów z ich pracownikami, odpowiedzialnymi za kontakty z zainteresowanymi podjęciem współpracy - potencjalnymi franczyzobiorcami. 
INNOWACYJNOŚĆ SIECI FRANCZYZOWYCH W POLSCE

Pierwszym argumentem przemawiającym za innowacyjnym charakterem sieci franczyzowych w Polsce jest ich nowość na polskim rynku. Pomimo ich dość powszechnego występowania na świecie (najwcześniej sieci franczyzowe rozwinęły się w Stanach Zjednoczonych Ameryki Północnej), w Polsce rozwijają się prężnie zaledwie od kilkunastu lat. Pierwsze sieci pojawiły się oczywiście na początku lat ' $90 \mathrm{XX}$ wieku, po uwolnieniu polskiego rynku. W roku 1995 było ich 23, a następnie liczba ta rosła dynamicznie (średni przyrost to niemal 28 sieci rocznie) do roku 2005 , kiedy to na polskim rynku działało 301 sieci franczyzowych. Po przestoju w roku 2005, od roku 2006 odnotowuje się dalszy, stały wzrost liczby sieci franczyzowych na polskim rynku. Zmniejszyła się co prawda dynamika wzrostu liczby sieci, w porównaniu z pierwszymi latami (w okresach 1995-2000 i 2000-2005 wzrost wynosił odpowiednio 413\% i 318\%, a w latach 2005-2010-219\%), lecz w latach 2006-2010, rocznie przybywało już średnio ponad 86 nowych systemów franczyzowych. Prognozowana na zakończenie 2011 roku liczba systemów franczyzowych wyniesie około 750. Jak zatem widać, liczba sieci franczyzowych stale odnotowuje od czasu pojawienia się w Polsce wzrost, nie zaburzony w żadnym stopniu choćby ostatnim kryzysem gospodarczym.

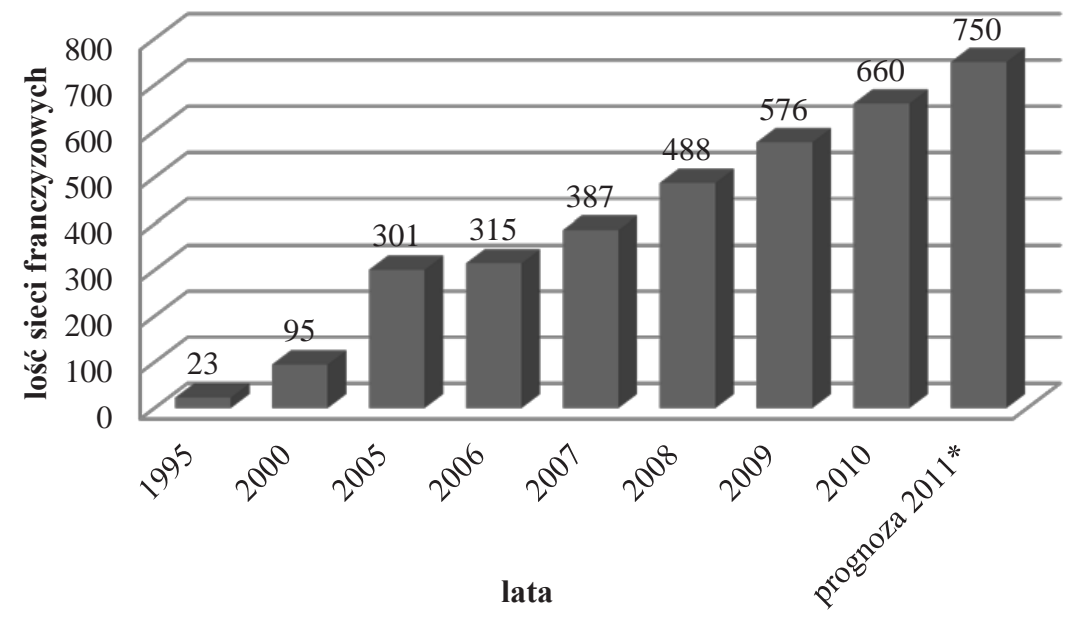

Ryc. 1. Liczba systemów franczyzowych w Polsce w latach 1995-2011*

Źródło: opracowanie własne na podstawie „Raportów o rynku franczyzy w Polsce w latach 2007-2010”

Rozwój rynku sieci franczyzowych w Polsce wyrażał się również w widocznym wzroście ilości placówek franczyzowych należących do przedsiębiorców działających w sieciach. W roku 2004 było ich w Polsce 17,260 i ich liczba stale rosła, by w zeszłym roku osiągnąć liczbę 38,269 placówek. Wzrost wynosił zatem we wskazanym okresie ponad 210\%, a w przeciągu ostatnich 6 lat przybyło ponad 20,000 nowych placówek. 


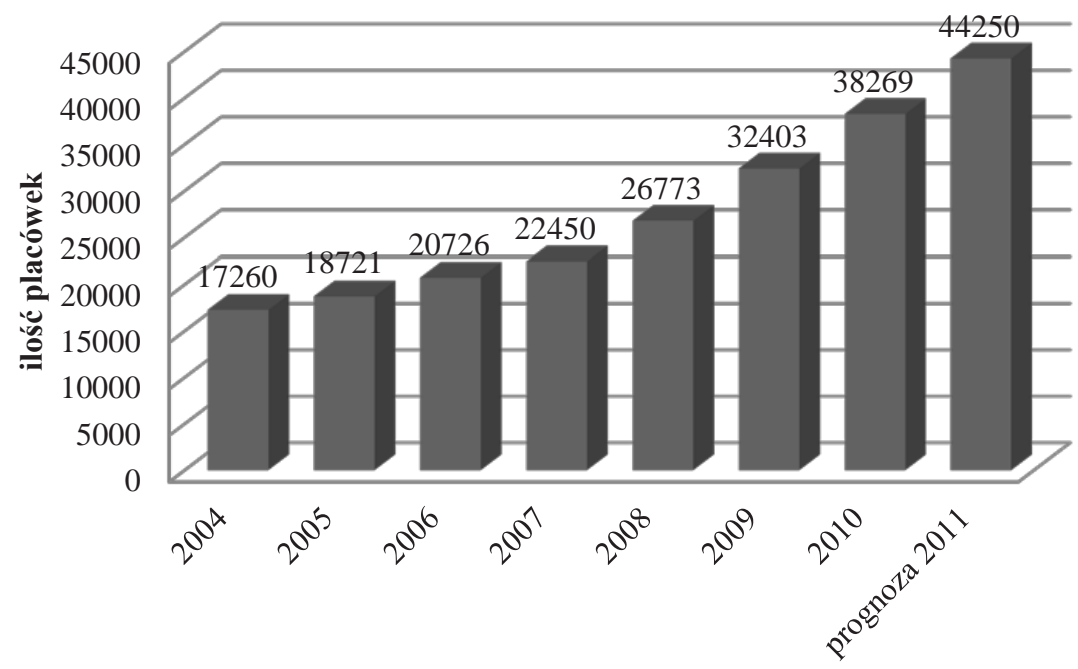

lata

Ryc. 2. Liczba placówek franczyzowych w Polsce w latach 2004-2011*

Źródło: opracowanie własne na podstawie „Raportów o rynku franczyzy w Polsce”

Tak jak w przypadku sieci, tak również w przypadku już konkretnych placówek, analizując dynamikę zmian ich liczebności w ostatnich latach nie dostrzega się wpływu kryzysu na ich rozwój, który zdaniem autorki powinien ukazać się w formie spadku, lub choćby spowolnienia wzrostu. Paradoksalnie zatem, zła sytuacja rynkowa może przyczyniać się do wzrostu sieci franczyzowych w Polsce.

Drugą cechą innowacyjną franczyz jest zatem ich odporność (jeśli wziąć pod uwagę ciągły wzrost ilości sieci i placówek) na negatywne skutki kryzysu gospodarczego, jako wyjątkowy sposób przystosowania przedsiębiorstwa do zmieniającej się sytuacji rynkowej. Z punktu widzenia przedsiębiorstw, a w szczególności kluczowych dla gospodarki małych firm, największym bezpośrednim zagrożeniem w okresie spowolnienia wzrostu gospodarczego, z jakim mają do czynienia w okresie kryzysu, jest często wzrost kosztów uzyskania przychodu, przy jednocześnie słabnącym popycie na oferowane towary i usługi. Przedsiębiorca zmuszony jest w takiej sytuacji do utrzymania cen produktów (i obniżenia marży) co oczywiście powoduje spadek zysku przedsiębiorstwa. W tej trudnej sytuacji, działający w ramach sieci franczyzowych, choć często są małymi, kilkuosobowymi przedsiębiorstwami, mogą czerpać korzyści płynące z wielkości całej sieci franczyzowej: mają większe możliwości negocjacji z dostawcami (przy dużo większej skali zamówień) zarówno w kwestiach finansowych jak i logistycznych. Korzyści finansowe, to: możliwość uzyskania niższej ceny towaru przy zwiększonej skali zamówień, większe możliwości korzystania z uczestnictwa w akcjach promocyjnych dostawcy (gratisowe produkty dla klientów), większe możliwości wynegocjowania odroczonych terminów płatności za towary i usługi, co ma często kluczowe znaczenie dla utrzymania płynności finansowej (szczególnie w czasie obniżonych obrotów 
przedsiębiorstwa w czasie kryzysu, lub w początkowym okresie działalności, gdy zwykle obroty firmy nie pokrywają wartości poniesionych inwestycji i kosztów bieżącej działalności). Korzyści logistyczne natomiast to np. obniżone koszty transportu przy większej liczbie odbiorców w postaci placówek franczyzowych, większe możliwości negocjacji minimum logistycznego, oraz częstotliwości dostaw.

Inną korzyścią wynikającą z rozwoju sieci franczyzowych w Polsce jest stworzenie nowych możliwości aktywizacji na rynku pracy, w szczególności młodych ludzi, wykształconych, lecz nie posiadających doświadczenia w pracy. Problemy młodych ludzi ze znalezieniem pracy paradoksalnie przyczyniają się do ich aktywizacji ekonomicznej, gdyż są motywem do poszukiwania dróg samozatrudnienia, poprzez zakładanie własnej działalności gospodarczej. Franczyza jest odpowiedzią na te poszukiwania. Daje możliwość szybkiego poznania branży i otworzenia własnej działalności gospodarczej, często bez doświadczenia. Zdecydowana większość zbadanych przez autorkę sieci franczyzowych nie wymaga od przyszłego franczyzobiorcy żadnego doświadczenia, a franczyzodawca wręcz argumentuje chęć współpracy z osobami niedoświadczonymi ich łatwiejszym przyswojeniem zasad działania sieci, w odróżnieniu od trudniejszego „oduczania” złych nawyków przedsiębiorców już w branży działających.

Rozpoczynanie działalności jako placówka franczyzowa ogranicza również ryzyko związane z niepowodzeniem, dzięki wykorzystaniu doświadczenia franczyzodawcy i jego sprawdzonego pomysłu na biznes. Wszyscy spośród zbadanych przez autorkę franczyzodawców oferują franczyzobiorcom pomoc zarówno w założeniu działalności, wyborze lokalizacji i otwarciu punktu franczyzowego (w tym często w uzyskaniu stosownych zezwoleń), jak i przekazaniu know-how na temat branży i prowadzenia placówki. Wiedza i doświadczenie franczyzodawcy i innych franczyzobiorców w sieci eliminuje nietrafione pomysły, a nowe (często innowacyjne) mogą być szybciej sprawdzane na rynku i mają na nim większą szansę powodzenia, dzięki wprowadzaniu ich w większej skali i poparciu szerszą akcją promocyjną. Wartość intelektualna w postaci wiedzy przedsiębiorstwa i jego pracowników, przekazywana przez franczyzodawcę swoim franczyzobiorcom jest bezcenna dla rozpoczynających działalność w branży, a także jest bardzo ważną wartością dodaną przedsiębiorstwa (Gierańczyk 2010).

Kolejną innowacyjną cechą franczyzy, związaną z poprzednim zagadnieniem jest niespotykana współpraca potencjalnych konkurentów. Samodzielne przedsiębiorstwa (jakimi są przecież przedsiębiorstwa franczyzowe), działające w jednej branży zwykle konkurują ze sobą, natomiast w przypadku franczyz jest inaczej - współpracują one nie tylko z franczyzodawcą, lecz również ze sobą, realizując zobowiązania wynikające z podpisanej z franczyzodawcą umowy i reprezentują niejako jeden front $\mathrm{w}$ walce o klienta $\mathrm{z}$ przedsiębiorstwami $\mathrm{z}$ poza sieci. Innowacyjność polega $\mathrm{w}$ tej kwestii zatem na przekazywaniu w ramach sieci, wśród tak naprawdę niezależnych przedsiębiorstw, wiedzy i doświadczenia, które zwykle są przez przedsiębiorstwa pilnie strzeżone. Franczyza sprzyja więc również rozpowszechnieniu innowacji.

Kolejną innowacyjnością jest sama forma współpracy przedsiębiorców w ramach franczyzy, którą zaliczyć należy do innowacji organizacyjnych. Polega ona na niezależności franczyzobiorców i wpływa pozytywnie na efektywność działalności placówek. Samodzielni przedsiębiorcy tworzący sieć mają większą motywację do działania i osiągnięcia sukcesu. Samodzielność franczyzobiorców jest również bardzo wygodną formą prowadzenia biznesu 
dla franczyzodawcy. Nie musi on stale monitorować dobrze działających placówek, a przynoszą mu one zysk.

Wracając jednak ponownie do rozważań związanych ze zwiększającą się liczbą placówek franczyzowych, należy stwierdzić, że wzrost ich liczby w stosunku do wzrostu liczby sieci jest znacznie niższy. Związane jest to ze sporym zróżnicowaniem wielkościowym sieci. W ramach wykonanego przez autorkę badania rynku franczyz w Polsce, w którym grupa badawcza stanowiła 372 losowo wybranych sieci (spośród 660 sieci istniejących na koniec 2010 r.) dokonano również analizy liczebności placówek otworzonych przez franczyzobiorców w ramach poszczególnych sieci. Z przeprowadzonych badań wynika, że najwięcej, bo niemal połowę $(48 \%)$ wśród sieci franczyzowych w Polsce, stanowią sieci małe, które posiadają do 10 placówek. Sieci posiadające 10-20 placówek, które również można uznać za stosunkowo małe, stanowią 18,5\% badanych. Od 20-50 placówek występuje w 16,5\% sieci, natomiast sieci większe, z liczbą powyżej 50 placówek stanowią łącznie 17\% rynku sieci franczyzowych w Polsce. O ile przy okazji omawiania korzyści dla franczyzobiorców w negocjacjach z dostawcami, autorka podkreślała pozytywy wynikające z jej znacznej wielkości jako całej sieci, o tyle w tym momencie odwrotnie - należy podkreślić korzyść wynikającą $\mathrm{z}$ tego, że przedsiębiorstwa franczyzowe to przedsiębiorstwa należące zatem do sektora MŚP, czyli do sektora, który jest źródłem innowacyjnych pomysłów (Turek 2005).
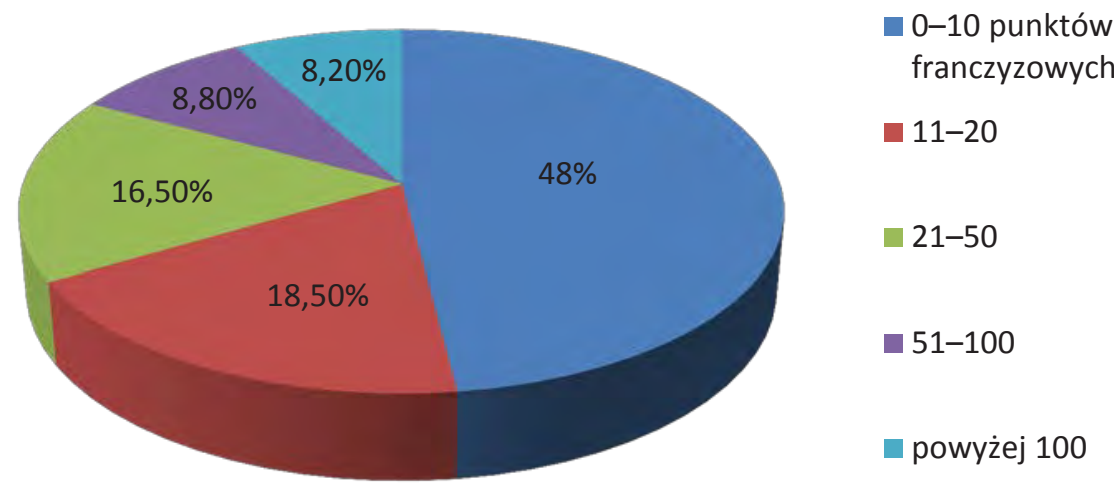

Ryc. 3. Zróżnicowanie wielkości sieci franczyzowych w Polsce w 2011 r.

Źródło: opracowanie własne na podstawie badań własnych

Kolejną istotną cechą, analizowaną przez autorkę jest znaczne zróżnicowanie branż, w jakich działają sieci franczyzowe na polskim rynku. Z przeprowadzonych przez autorkę badań, które objęły tę samą próbę 372 sieci, wynika, że rynek franczyz jest zdominowany przez działalność gastronomiczną, handlową i usługową. Największy udział mają w nim punkty gastronomiczne (21\% badanych), w których skład autorka zaliczyła bardzo różne formy, od restauracji, przez cukiernie, lodziarnie, aż po bary fast-food. Na drugim miejscu znalazły się sklepy spożywcze (17\% sieci). Znaczny udział (po 8\% sieci) stanowią również szkoły, ośrodki szkoleń, oraz salony urody (w skład których wliczono głównie salony kosmetyczne, solaria i zakłady fryzjerskie), a na kolejnych miejscach uplasowały się sklepy budowlane i z wyposażeniem wnętrz (7\% badanych sieci) oraz sklepy spożywcze (7\%). Pojawiającymi 
się również, choć już ze znacznie mniejszą częstotliwością sieciami były: salony telekomunikacyjne i GSM, biura podróży, biura nieruchomości, oraz apteki. Najliczniejszą wśród badanych grupę (21\%) stanowiły jednak sieci, które autorka była zmuszona zaliczyć do kategorii ,inne”. Fakt ogromnego zróżnicowania przedmiotu działalności tych sieci (od myjni samochodowych, przez pralnie ekologiczne, kwiaciarnie, agencje reklamy, aż po kliniki antynikotynowe i kancelarie prawne) spowodował, że nie sposób było je pogrupować. To jednak właśnie wśród nich najczęściej spotykano pomysły i produkty innowacyjne.

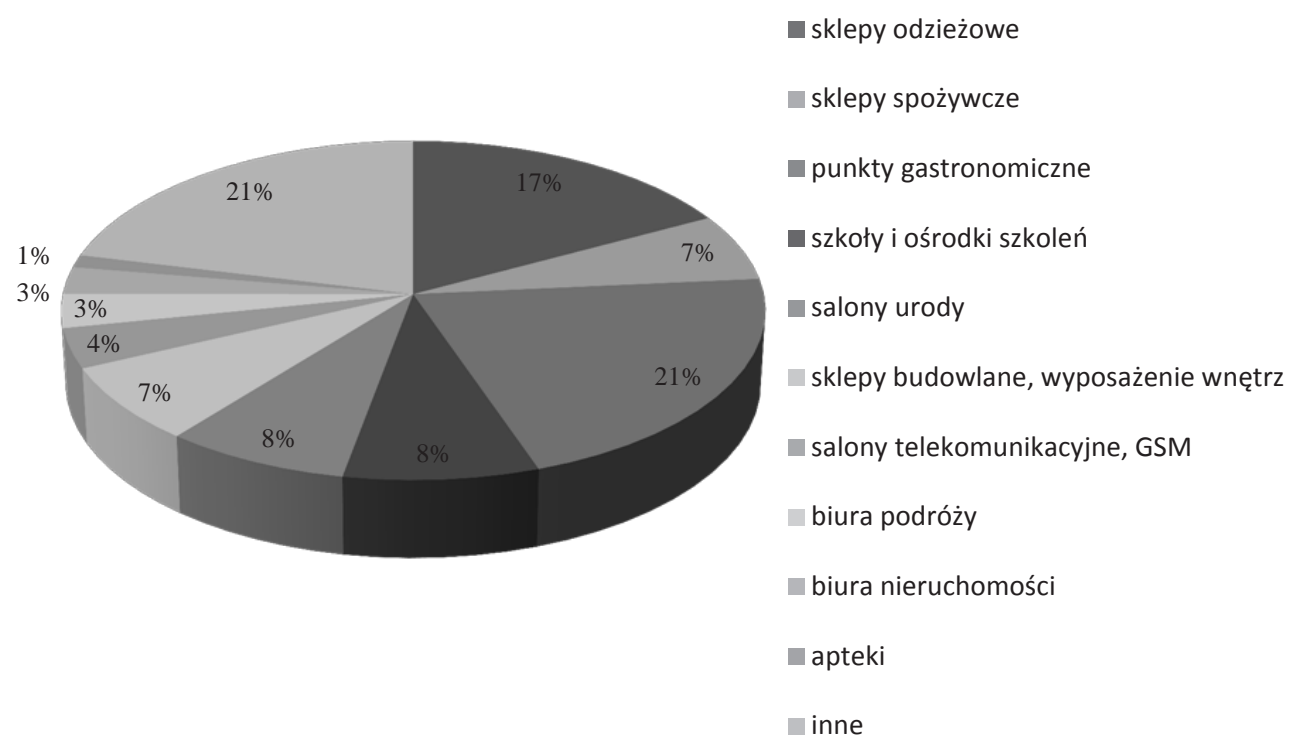

Ryc. 4. Rodzaje działalności badanych sieci franczyzowych w Polsce w 2011 r.

Źródło: opracowanie własne na podstawie badań własnych

Istotnym aspektem podjętych przez autorkę badań była również analiza poziomu inwestycji ponoszonych przez franczyzobiorców na otwarcie pierwszej placówki franczyzowej. Zgodnie z danymi zgromadzonymi na podstawie „Raportów o rynku franczyzy w Polsce” w latach 2006-2010, średnia inwestycja franczyzobiorcy w nowo otwieraną placówkę spada. W roku 2006 wynosiła ona 380 tys. zł i spadała do 2008 roku, gdy wyniosła 260 tys. zł. W kolejnym roku nastąpił niewielki wzrost, lecz na koniec $2010 \mathrm{r}$. znów odnotowano spadek i średnia inwestycja w nowo otwieraną placówkę wg ostatnich danych to 241,4 tys. zł. Spadek średniej inwestycji w nowe punkty franczyzowe wynika z rozszerzającej się oferty sieci wymagających niskiego wkładu początkowego. Kwota 241,4 tys. zł wydaje się być zaporowa dla większości młodych ludzi, lecz w istocie nie jest ona wymierna, gdyż zróżnicowanie poziomu inwestycji pomiędzy poszczególnymi sieciami jest ogromne (od kilku tysięcy zł na otwarcie małego sklepu, po około 1,5 $\mathrm{mln}$ zł na restaurację McDonald's). 


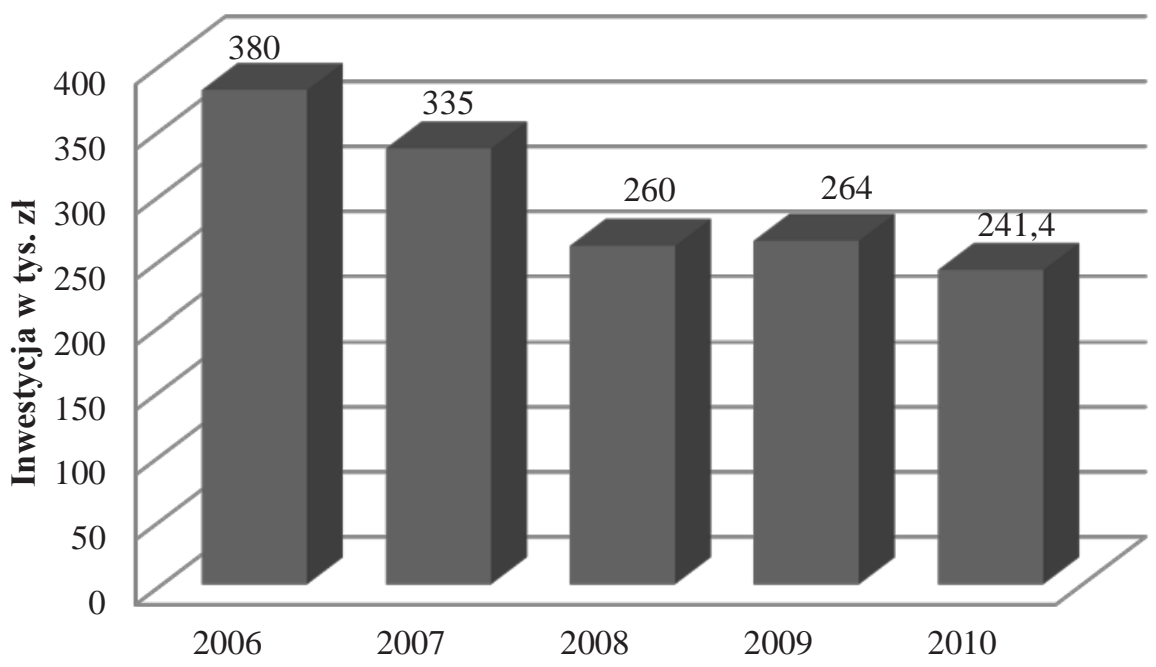

Ryc. 5. Średnia inwestycja franczyzobiorcy w nowo otwieraną placówkę w latach 2006-2010

Źródło: opracowanie własne na podstawie „Raportów o rynku franczyzy w Polsce”

Autorka postanowiła więc określić poziom owego zróżnicowania wśród badanych franczyz. Jak wynika z przeprowadzonych badań, największą grupę, aż 22,3\%, stanowią franczyzy, które wymagają bardzo niskich nakładów - do 20 tys. zł. Inwestycje na poziomie 21-50 tys. zł stanowią 19,6\%, a 51-80 tys. zł trzeba przeznaczyć na nową placówkę w 18,3\% sieci. Wśród ponad połowy sieci poziom inwestycji jest zatem osiągalny dla większości ludzi. Innowacyjność oferowana przez sieci franczyzowe jest zatem, w przeciwieństwie do innowacyjności w jej powszechnym rozumieniu, w finansowym zasięgu ręki.

W tym momencie należy również wspomnieć o kosztach ponoszonych przez franczyzobiorcę na rzecz franczyzodawcy. Opłaty ponoszone są z tytułu umowy franczyzowej zawierającej obowiązki franczyzodawcy wobec klienta i sprowadzają się do przekazywania wiedzy i pomocy franczyzodawcy w założeniu i bieżącym prowadzeniu działalności. Najczęściej koszty te obejmują stałą opłatę franczyzową, zwykle uzależnioną od osiąganego przez franczyzobiorcę zysku. Nie sposób w niniejszej pracy określić nominalnie tych kosztów, gdyż są one ustalane indywidualnie w każdej umowie franczyzowej i zapewne bardzo zróżnicowane w zależności od skali pomocy franczyzodawcy i ponoszonych przez niego kosztów. System franczyzowy zakłada więc stałe zobowiązanie finansowe franczyzobiorcy wobec franczyzodawcy, lecz przekazywana przez sieć wiedza i pomoc, szczególnie w początkowym okresie działalności wydaje się być bezcenna w obliczu tak licznej grupy przedsiębiorstw upadających w początkowym okresie działalności. 


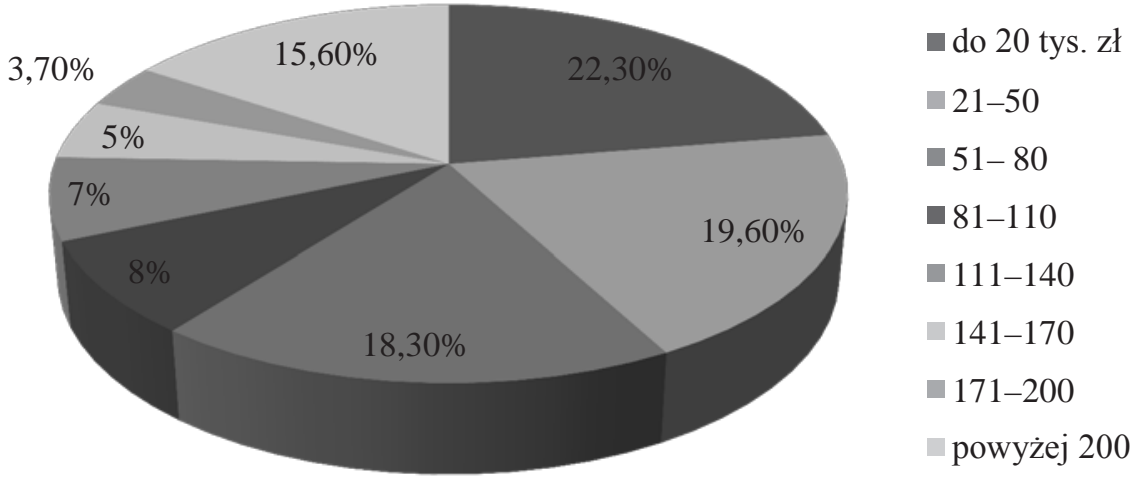

Ryc. 6. Zróżnicowanie kosztów jakie należy ponieść na założenie nowej placówki franczyzowej w badanych sieciach franczyzowych w Polsce w 2011 r.

Źródło: opracowanie własne na podstawie badań własnych

Kolejną istotną cechą sieci franczyzowych, która również była analizowana przez autorkę jest zróżnicowanie własnościowe sieci. Na polskim rynku, od początku pojawienia się franczyz, występowała przewaga sieci rodzimych nad sieciami zagranicznymi. Według danych zgromadzonych w „Raportach o rynku franczyzy w Polsce” za lata 2006-2010 wynika, że w roku 2006 sieci zagraniczne stanowiły niespełna 1/3 sieci $(29,4 \%)$, w 2007 roku $28,7 \%$, w $2008-28,1 \%$, w 2009 - 27,4\%, a w 2010 - 27,1\%. Należy więc stwierdzić, że na polskim rynku franczyzowym, przy stałym wzroście liczby sieci stosunek sieci rodzimych i zagranicznych utrzymuje się na niemal identycznym poziomie. Nie jest zatem tak, jak mogłoby się pozornie wydawać, że polski rynek jest zdominowany przez rozprzestrzeniające się sieci zagraniczne. Ponadto prężnie rozwijające się polskie sieci coraz częściej wykraczają swym zasięgiem przestrzennym poza granice naszego kraju. Na koniec 2010 r. aż 72 polskich sieci posiadało swoje placówki poza granicami naszego kraju (Raporty o rynku franczyzy w Polsce w latach 2007-2010). Rozprzestrzenianie się polskich sieci franczyzowych jest zdaniem autorów przytoczonego raportu „ucieczką do przodu” na wypadek spowolnienia rozwoju przedsiębiorstw w kraju w przypadku drugiej fali kryzysu ekonomicznego w Europie.

Pierwsze polskie sieci franczyzowe pojawiały się w Czechach, natomiast aktualnie główne kierunki ekspansji polskich sieci to już prócz Czech: Rosja, Słowacja, Ukraina i Litwa (Raporty o rynku franczyzy w Polsce w latach 2007-2010). Łatwość w rozprzestrzenianiu się sieci franczyzowych jest ich kolejną cechą innowacyjną. Wkroczenie na zagraniczny rynek jest dzięki uczestnictwu w sieci zdecydowanie łatwiejsze z racji wiedzy na temat wymagań owego rynku (zarówno wymagań i gustów klientów, jak i wymogów prawnych) przekazywanej przez franczyzodawcę, jego pomocy i monitoringu działań. 


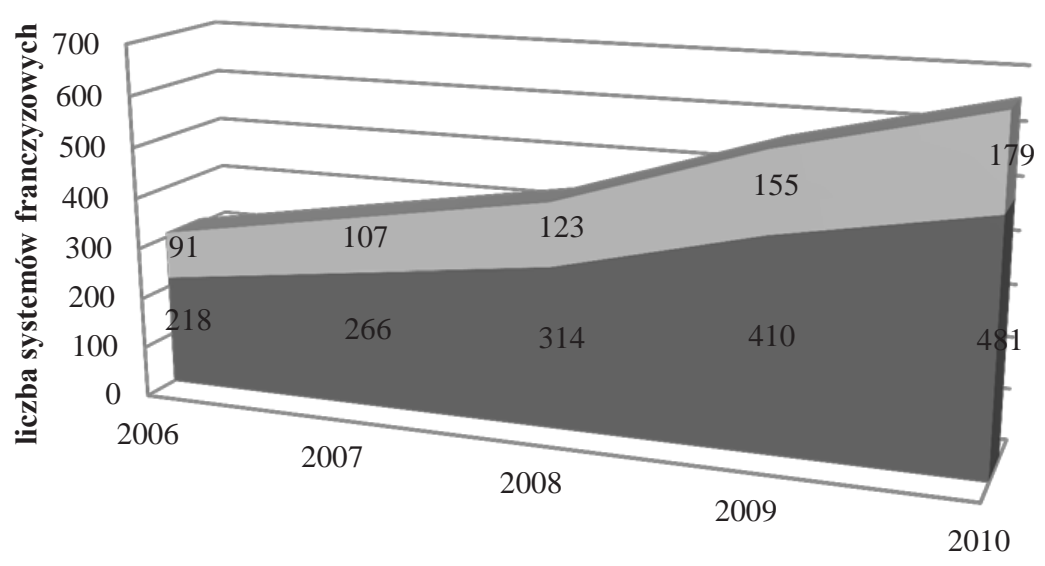

• polskie systemy franczyzowe $\square$ zagraniczne systemy franczyzowe

Ryc. 7. Rodzime i zagraniczne sieci franczyzowe na polskim rynku w latach 2006-2010

Źródło: opracowanie własne na podstawie „Raportów o rynku franczyzy w Polsce w latach 2007-2010”

\section{PRZYKLADY INNOWACJI TECHNICZNYCH, RYNKOWYCH I ORGANIZACYJNYCH SIECI FRANCZYZOWYCH W POLSCE}

Analizując listę wybranych 372 sieci franczyzowych w Polsce autorka niejednokrotnie dziwiła się jak liczna jest grupa znanych marek, których przedsiębiorstwa działają na zasadach franczyzy. Jak się okazuje, z racji zdominowania rynku franczyzy przez przedsiębiorstwa handlowe i usługowe, autorka ośmiela się stwierdzić, że idąc alejką w centrum handlowym, zdecydowana większość butików z jakimi się spotykamy to placówki franczyzowe. Dla przykładu, wymieniając alfabetycznie bardziej znane marki, należy wskazać choćby: Abc, Abra, Atlantic, Carrefour Express, Da Grasso, Diverse, Ecco, Ecco Holiday, Greenpoint, Groszek, InPost, Kukartka, Lee Cooper, Levi’s, McDonald’s, Pizza Dominium, Profi-Lingua, Ravel, Reserved, Sphinx, Subway, Tatuum, Telepizza, YvesRocher, Żabka, czy salony: telekomunikacyjne Play, Orange, Netia, urody dr Ireny Eris czy makijażu Inglot. Placówki franczyzowe są zatem wszechobecne.

Pomimo wspomnianej dominacji branży handlowej i usługowej, uznawanej powszechnie za mało innowacyjną, wśród zbadanych sieci autorka wyodrębniła $58(15,6 \%)$ sieci o znamionach innowacji. Były to zgodnie z przyjętą definicją innowacji M. Haferra (2004) innowacje zarówno techniczne, rynkowe jak i organizacyjne. Przez innowacje techniczne autorka rozumie wprowadzane przez przedsiębiorstwa nowe, technologicznie zaawansowane produkty (w tym również usługi), przez innowacje rynkowe - produkty bazujące na znanych wcześniej rozwiązaniach, lecz nowe na polskim rynku, lub w nowatorski sposób łączące istniejące rozwiązania, a przez innowacje organizacyjne - szeroko rozumiane nowe koncepty organizacyjne przedsiębiorstw. 
Spośród badanych przez autorkę, przykładami przedsiębiorstw różnych branż, w których występują innowacje techniczne można wskazać choćby: Dermatis, Fly3Dmap, Lampe Berger Paris, No+vello, Oxyclub \& Epil Center, Tansphere czy Tornado Pizza. Przedsiębiorstwa te wprowadzają i rozpowszechniają na rynku bardzo zróżnicowane innowacje. Dermatis to sieć salonów kosmetycznych, w których do zabiegów fotodepilacji, fotoodmładzania, leczenia rozszerzonych naczynek, trądziku i usuwania przebarwień wykorzystywane jest innowacyjne narzędzie w postaci intensywnego światła pulsowego. W innowacyjności w dziedzinie kosmetologii wyprzedza jednak poprzednie przedsiębiorstwo firma Oxyclub \& Epil Center, która udoskonaliła poprzednią technologię, wykorzystując w zabiegach urządzenie IPL+RF (połączenie intensywnego impulsowego światła $\mathrm{z}$ falą radiową), oraz wprowadziła na rynek urządzenie oxybrazja (do tlenowego zabiegu złuszczania naskórka i pielęgnacji twarzy). Poza dziedziną kosmetologii, we wskazanych przykładach podano Fly3Dmap, przedsiębiorstwo, które stworzyło autorską interaktywną aplikację 3D stanowiącą połączenie trójwymiarowej mapy z wirtualnym przewodnikiem po centrach największych miast, lotniskach, obiektach użyteczności publicznej, pozwalającą tworzyć indywidualizowane mapy $3 \mathrm{D}$ z trójwymiarowymi obiektami, czy wreszcie Tornado Pizza - pizzerię będącą pomysłodawcą pizzy o niespotykanym kształcie przypominającym rulon.

Innowacje rynkowe wprowadzane były spośród badanych przez choćby takie przedsiębiorstwa jak: Coffe News, Bajart, Family Care, Natur House, PCDOC pogotowie komputerowe, Restauracja Robotów, Steam Art czy Zakłady Piekarskie „Oskroba”. W tym przypadku zróżnicowanie było jeszcze większe. Dla przykładu - firma PCDOC pogotowie komputerowe to firma świadcząca pełne usługi związane głównie z naprawą komputerów i połączeń internetowych $7 \mathrm{dni}$ w tygodniu $24 \mathrm{~h}$ na dobę, a charakterystyczny strój i wyposażenie serwisanta przypominają atrybuty prawdziwego lekarza pogotowia. Restauracja Robotów to restauracja, gdzie obsługą klientów zajmują się mechaniczni kelnerzy, klienci dokonują zamówienia za pomocą dotykowych wyświetlaczy, złożone zamówienie dociera drogą elektroniczną do kuchni gdzie następuje przygotowanie posiłku, a gotowe danie trafia na tacę która zostaje dostarczona przez robota do stołu klienta. Roboty na specjalne życzenie klienta mogą dodatkowo zaprezentować taneczne show (strona internetowa Franchising. pl). Zakłady Piekarskie „Oskroba” natomiast, to sieć specjalistycznych sklepów - piekarni, w których pieczywo wypiekane jest na miejscu (a nie dowożone), na oczach klienta. W piekarniach prezentowany jest klientom pełen proces produkcyjny niektórych produktów, w którym mogą uczestniczyć.

Natomiast do przedsiębiorstw innowacyjnych pod względem organizacyjnym zaliczono: Tim S.A., World Seo, Świat Nieruchomości czy Print Terminal. Dla przykładu - World Seo to sieć zajmująca się handlem bardzo zróżnicowanymi towarami przez Internet. Działalność sieci oparta jest na outsourcingu i rodzaju dropshippingu (logistyczna metoda zarządzania towarem, w którym sprzedawca sam nie magazynuje towaru a w zamian kieruje zamówienia swoich klientów oraz szczegóły wysyłki do producenta lub hurtownika, który następnie realizuje wysyłkę bezpośrednio do klienta), poprzez sprawdzony program biznesowy umożliwiający handel w sklepach i na aukcjach internetowych produktami bezpośrednio z fabryk bez pośredników. Print Terminal natomiast to sieć terminali poligraficzno-reklamowych, w której wyjątkowym rozwiązaniem organizacyjnym jest samodzielne prowadzenie własnych drukarni (połączonych często z agencją reklamową) przez franczyzobiorców (specyficzna decentralizacja produkcji wydawniczej). 
Opisane (choć po krótce i w niewielkiej liczbie) przykłady pokazują, w jak różnym stopniu może realizować się na rynku myśl innowacyjna i jak często odbiega ona od powszechnych skojarzeń i prostego rozumienia - czego idealnym przykładem są innowacje w handlu i gastronomii.

\section{Podsumowanie}

Trwały sukces działalności przedsiębiorstw niezależnie od ich lokalizacji, charakteru, wielkości i branży, uzależniony jest dziś od stopnia ich innowacyjności. Innowacyjność jest sposobem współczesnych przedsiębiorstw na utrzymanie się na zmieniającym się rynku i odpowiedź na potrzeby klientów, w tym ich kształtowanie, lecz również poszukiwanie dróg rozwoju wewnętrznego przedsiębiorstwa, w szczególności w zakresie jego organizacji. Innowacyjność współcześnie nie może i nie ogranicza się do tworzenia nowych rozwiązań technologicznych, a następnie wprowadzania ich do produkcji przemysłowej. W toku badań i rozważań poczynionych w niniejszym artykule, autorka potwierdziła swoją tezę, że szczególnym rodzajem nowoczesnego modelu biznesu, który w Polsce rozwija się od niedawna, a jest przykładem organizacji innowacyjnej na wielu polach jest franczyza. Podsumowując przedstawione w artykule wyniki badań własnych autorki oraz danych zgromadzonych głównie na podstawie „Raportów o rynku franczyzy w Polsce”, należy stwierdzić, że innowacyjność sieci franczyzowych (rozumianą bardzo szeroko) należy rozpatrywać na dwóch poziomach. Pierwszym są innowacyjne rozwiązania występujące we franczyzach w ogóle, wynikające $z$ charakteru sieci franczyzowych, natomiast drugim - konkretne, specyficzne rozwiązania wprowadzane przez poszczególne sieci franczyzowe. Głównymi argumentami wskazanymi przez autorkę a przemawiającymi za innowacyjnością sieci franczyzowych w Polsce są: rozwijanie się prężnie na polskim rynku dopiero od 10 lat, oryginalna forma organizacji przedsiębiorstw, zwiększająca ich szansę na przetrwanie w czasach kryzysu, sprzyjanie aktywizacji zawodowej na rynku pracy, poprzez zakładanie działalności gospodarczej głównie przez młodych, przedsiębiorczych ludzi, przekazywanie przez franczyzodawcę wiedzy i doświadczenia zarówno w zakresie otwarcia i prowadzenia placówki, jak i całej branży, niespotykana współpraca potencjalnych konkurentów, jaka występuje wewnątrz sieci - wśród niezależnych przedsiębiorców, jednoczesne korzystanie z przywilejów zarówno dużej jak i małej firmy (np. zwiększone możliwości współpracy z dostawcami [logistyczne i cenowe]), szybkie rozpowszechnianie innowacyjnego produktu przez franczyzobiorców, czy łatwość w zwiększaniu zasięgu przestrzennego działalności. Natomiast wśród rodzajów innowacji wprowadzanych przez poszczególne badane sieci dostrzeżono wszystkie trzy rodzaje innowacji wskazane w jednej z przyjmowanych definicji: innowacje o charakterze technicznym, rynkowym oraz organizacyjnym. W artykule celowo nie skupiano się na, występujących oczywiście obok korzyści - negatywnych skutkach bycia członkiem sieci franczyzowej, takich jak: kosztach ponoszonych na rzecz franczyzodawcy (głównie stałych opłat licencyjnych, gdyż nie da się ich jednoznacznie i wiarygodnie ocenić), czy ograniczeniach wynikających z obowiązku przestrzegania zasad uczestnictwa w sieci (np. zakazie wprowadzania do sprzedaży produktów firm konkurencyjnych do tych, z którymi cała sieć ma podpisane umowy o współpracy). Cechy negatywne nie miały znaczącego wpływu dla rozważań autorki skierowanych na innowacyjność franczyz, a ich zestawienie z pozytywami i ocena powinny być przedmiotem rozważań w odrębnej pracy. 


\section{Literatura}

Borowiec M., Rachwał T., 2011, Ksztaltowanie postaw przedsiębiorczych na lekcjach geografii wyzwaniem edukacyjnym $w$ procesach globalizacji, Przedsiębiorczość-Edukacja, nr 7, Nowa Era, Zakład Przedsiębiorczości i Gospodarki Przestrzennej Instytutu Geografii Uniwersytetu Pedagogicznego w Krakowie, Warszawa-Kraków, s. 320-323.

Gierańczyk W., 2010, Rola własności intelektualnej w budowaniu innowacyjności krajów UE, [w:] Procesy przemian przemystu i uslug w wybranych krajach, pod red. Z. Zioło i T. Rachwała, Prace Komisji Geografii Przemysłu Polskiego Towarzystwa Geograficznego, nr 16, Wydawnictwo Naukowe UP, Warszawa-Kraków, s. 76-77.

Haffer M., Kraszewski W. (red), 2004, Czynniki wzrostu gospodarczego, Wyd. Uniwersytetu im. Mikołaja Kopernika, Toruń, s. 337.

Schumpeter J.A., 1960, Teoria rozwoju gospodarczego, PWN, Warszawa, s. 104.

Turek M., 2005, Edukacja dla innowacji i przedsiębiorczości, [w:] Innowacyjność w nauce, edukacji $i$ gospodarce, pod red. Jerzego Błażejowskiego, Gdańskie Towarzystwo Naukowe, Gdańsk, s. $90-108$.

\section{Strony internetowe}

„Raporty o rynku franczyzy w Polsce” w latach 2007-2010, http://franchising.pl/aktualnosci/raporty/ Portal internetowy Franchising.pl, http://franchising.pl/artykuly/wszystkie/

Strona internetowa Polskiej Organizacji Franczyzodawców, http://franczyza.org.pl/

\section{Innovation of franchise networks}

A lasting success of business activities regardless of their location, nature, size and industry is now dependent on the degree of innovation. Innovation is a way for modern enterprises to survive in the changing market, and a response to customer needs, including their formation, but also seeking ways to develop the internal businesses, particularly in its organization and ideas. Innovation today cannot be limited to the creation of new technological solutions, and then their implementation into industrial production. A particular kind of a modern business model, which has been recently developing in Poland and which is an example of an innovative organization in many fields, is the franchise, the focus of this article.

In the article, the principles of operation and the current state of development of franchise networks in Poland is explained, and then the innovative features of franchise business in general, resulting from franchise agreements, are analyzed. In the final part of the article, examples of innovations are presented: technological, market and organizational innovations, used in various franchise industries. In the article, the author also pays attention to the unique character of the franchise system, based on assistance and transfer of know-how to its franchisees by the entrepreneur, which reduces the risk arising from the start-up of new economic activity, and affects the fast and multi-dimensional development of franchise networks.

Mgr Agnieszka Świętek

Uniwersytet Pedagogiczny w Krakowie

Instytut Geografii

Zakład Dydaktyki Geografii

e-mail: swietekaga@wp.pl 